九州大学学術情報リポジトリ

Kyushu University Institutional Repository

\title{
Evaluation of Finger-jointed Laminae for Glulam Timber by Acousitic Emission I Development of Jig for Acoustic Emission Sensor Installed to Production Line and its Verification Test
}

Ohuchi, Takeshi

Laboratory of Wood Working, Department of Technology, Fukuoka University of Education

Murakami, Yuki

Laboratory of Wood Material Technology, Department of Forest and Forest Products Sciences, Graduate School of Bioresource and Bioenvironmental Sciences, Kyushu University, Kyushu University

Fuj imoto, Noboru Laboratory of Wood Material Technology, Division of Biomaterial Science, Department of Forest and Forest Products Sciences, Faculty of Agriculture, Kyushu University

https://doi.org/10.5109/16132

出版情報：九州大学大学院農学研究院紀要. 54 (2)，pp.467-470，2009-10-29. Faculty of Agriculture, Kyushu University

バージョン :

権利関係 : 


\title{
Evaluation of Finger-jointed Laminae for Glulam Timber by Acoustic Emission I Development of Jig for Acoustic Emission Sensor Installed to Production Line and its Verification Test
}

\author{
Takeshi OHUCHI*1, Yuki MURAKAMI ${ }^{2}$ and Noboru FUJIMOTO ${ }^{3}$
}

\author{
Laboratory of Wood Material Technology, Division of Biomaterial Science, Department of Forest and \\ Forest Products Sciences, Faculty of Agriculture, Kyushu University, \\ Fukuoka 812-8581, Japanese \\ (Received June 30, 2009 and accepted July 13, 2009)
}

\begin{abstract}
In end-jointing of laminae for the glulam timber, finger-joint is generally used. However, the strength properties of the glulam timber greatly decrease by slippage-off and destruction in starved joints of fingerjointed part when the laminae with starved joints in the finger-joint are located on the external layer of the glulam timber. Therefore, for the glulam timber with good strength properties, the evaluation of finger-joint properties after finger-jointing is important, and the method is hoped to be simple and non-destructive.

In this study, hinoki (Chamaecyparis obtua) finger-jointed laminae with starved joints (NH-laminae) and without starved joints (C-laminae) were prepared, respectively. The evaluation of finger-joint properties with a special attachment (jig) for installing the acoustic emission (AE) monitoring method into the production line of the laminae was conducted. That is, bending tests for these laminae with the jig were performed, and $\mathrm{AE}$ generated during the bending test was measured along with the load. Then, $\mathrm{AE}$ characteristics and bending strength properties of these laminae were examined. In addition, the verification test with the jig was performed. The main results are summarized as follows: AE signals of NH-laminae in the threshold of $20 \mathrm{mV}$ were measured at the early stage in bending test as compared with C-laminae. The $\mathrm{AE}$ generation load of NH-laminae showed a small value and showed the smallest value in $20 \mathrm{mV}$. From these results, it became clear that $\mathrm{AE}$ technique with the jig in the threshold of $20 \mathrm{mV}$ will be promising for the detection of the difference between $\mathrm{C}-$ and $\mathrm{NH}$-laminae at the early stage during bending test. From the obtained result of the verification test with the jig under the conditions of the load: $4 k N$ and the threshold: $20 \mathrm{mV}$ for the detection of the starved joints, it became clear that NH-laminae could be detected at the probability of about $70 \%$ under these conditions. Therefore, in the case of loading to the finger-jointed part of laminae in $4 \mathrm{kN}$ as the detection load with the jig, the possibility of the detection of the starved joints by $\mathrm{AE}$ as a non-destructive method was suggested.
\end{abstract}

\section{INTRODUCTION}

In generally, the performance of wood-based materials is technologically guaranteed, and the difference of strength properties of wood-based materials is very small as compared with solid woods. The glulam timber used widely as a structural material of wooden house is the main kind of wood-based materials. The glulam timber has the characteristics which can be manufactured heavy section and large-scale by laminating the endjointed laminae to secure the length needed as materials for large wooden buildings. In end-jointing of laminae, finger-joint is generally used. However, the strength properties of the glulam timber greatly decrease by slippage-off and destruction of fingers in starved joints of finger-jointed part when the laminae with starved joints in the finger-joint are located on the external layer. Therefore, for the glulam timbers with good strength

\footnotetext{
Laboratory of Woodworking, Department of Technology, Fukuoka University of Education

Laboratory of Wood Material Technology, Department of Forest and Forest Products Sciences, Graduate School of Bioresource and Bioenvironmental Sciences, Kyushu University

Laboratory of Wood Material Technology, Division of Biomaterial Science, Department of Forest and Forest Products Sciences, Faculty of Agriculture, Kyushu University

* Corresponding author (E-mail: tohuchi@fukuoka-edu.ac.jp)
}

properties, the evaluation of finger-joint properties after finger-jointing is important, and the method is hoped to be simple and non-destructive.

In our previous studies, we paid attention to acoustic emission (AE) as a non-destructive method, and bending test for finger-jointed laminae with starved joints has been performed. AE generated during bending test has also been investigated. From these obtained results, $\mathrm{AE}$ technique was promising for the detection of starved joints in the finger-joint at the early stage of the bending test (Ohuchi et al., 2004). In addition, we clarified that the position of starved joints in finger-joint could be presumed by one-dimensional method of using $\mathrm{AE}$ signal (Yano et al., 2007).

In consideration of installing $\mathrm{AE}$ monitoring method into the production line of finger-jointed laminae, the objective of this study was to obtain the basic information on evaluation of laminae in production line by $\mathrm{AE}$. In this experiment, a special attachment (jig) for the $\mathrm{AE}$ sensor installed into the production line was developed. hinoki (Chamaecyparis obtua) finger-jointed laminae with starved joints in the finger-joint part were prepared, and the evaluation of finger-joint properties was conducted by $\mathrm{AE}$ with the jig as the non-destructive method. That is, bending tests for these laminae were performed, and $\mathrm{AE}$ generated during bending tests was measured along with the load. Then, AE characteristics and bending strength properties were examined. Moreover, from 
these obtained results, bending load for detecting finger-joint laminae with starved joints was examined, and the verification test with the jig was performed under the bending load.

\section{MATERIALS AND METHODS}

\section{Specimens}

Specimens used in this study were made from hinoki (Chamaecyparis obtua) laminae. The mean specific gravities and the mean moisture contents of specimens were 0.52 and $11.2 \%$, respectively. These laminae were sorted not to have any knots or faults within $100 \mathrm{~mm}$ of the tip of finger-joint, and short-length laminae were made. The profile of the finger-joint was as shown in Fig. 1, where $\mathrm{l}=14.0 \mathrm{~mm}, \mathrm{p}=3.9 \mathrm{~mm}, \mathrm{t} 1=0.7 \mathrm{~mm}, \mathrm{t} 2=$ $0.6 \mathrm{~mm}$, and $\theta=4$ in 98 . These laminae were fingerjointed using aqueous polymer solution-isocyanate adhesive for wood (API) and end pressed at $9.2 \mathrm{~N} / \mathrm{mm}^{2}$. The adhesive was spread on the laminae before pressing, and the specimens were cured under room temperature for more 48 hours after adhesion. In finger-jointing laminae, two types laminae were manufactured as follows; the laminae finger-jointed by using API combined curing agent (hardener) with base resin at weight ratio 100:10 was assumed as C-Laminae (control specimen). The other laminae finger-jointed by using API without hardener was assumed as NH-lamimae (with starved joint). The size of finger-joint laminae for bending test was $110 \mathrm{~mm}$ wide, $21.5 \mathrm{~mm}$ thick, and $450 \mathrm{~mm}$ long.

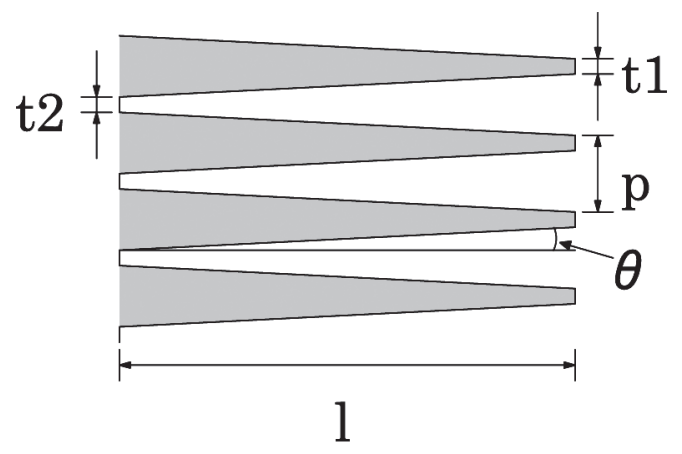

Fig. 1. Profile of the finger-joint.

\section{AE monitoring method during bending test}

Figure 2 shows a schematic diagram of the bending test and $\mathrm{AE}$ measurement. A static bending test for all specimens was conducted by three-point loading using the Instron mode strength test machine. The span was $330 \mathrm{~mm}$, and the crosshead speed was set at $5.0 \mathrm{~mm} / \mathrm{min}$. The modulus of elasticity (MOE) and modulus of rupture (MOR) were measured and recorded for each specimen. In addition, the $\mathrm{AE}$ generations during the bending test were measured along with load. In consideration of installing $\mathrm{AE}$ monitoring method into the production line, a special attachment (jig) for AE-sensor installed to the production line was developed as shown in Fig. 3. Two AE-sensors were mounted on each side of the jig using electron wax as a couplant. This jig was set up in the test machine as an emphasis of bending test. Thus, it was possible to evaluate the finger-jointed laminae continuously without replacing $\mathrm{AE}$ sensors by using this jig. The $\mathrm{AE}$ signals received by $\mathrm{AE}$ sensors of the jig during bending tests was amplified to $40 d B$ by a preamplifier and additionally amplified to $40 \mathrm{~dB}$ by a main amplifier. The threshold level was set to 20, 40, $60 \mathrm{mV}$, respectively. Accumulated $\mathrm{AE}$ count, $\mathrm{AE}$ count rate, and the load that $\mathrm{AE}$ generation started during bending tests were investigated, respectively.

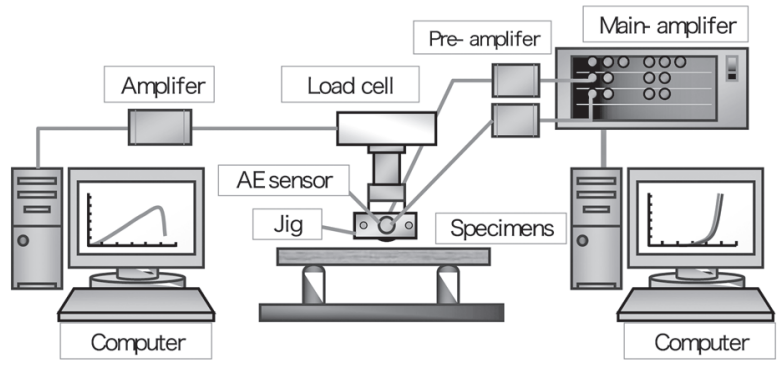

Fig. 2. Schematic diagram of bending test and $\mathrm{AE}$ measurement in this study.

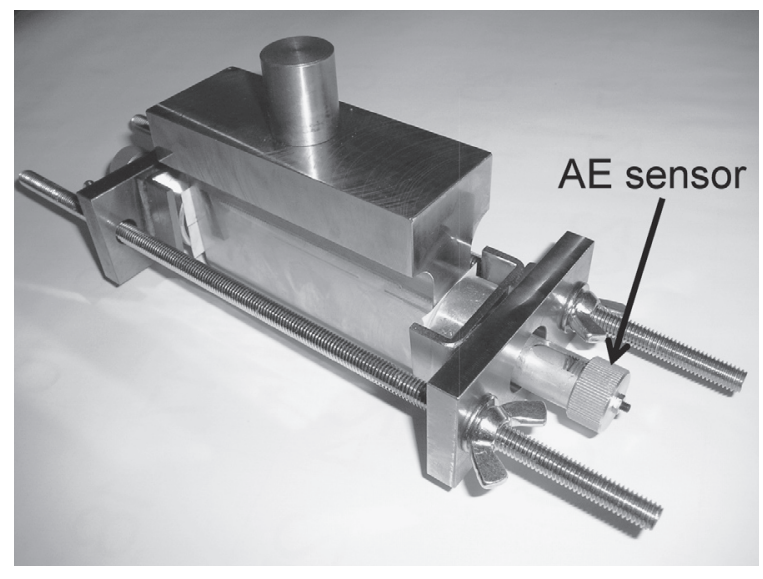

Fig. 3. Photograph of a special attachment (jig) for AE sensor.

\section{RESULTS AND DISCUSSION}

\section{Behavior of AE generation}

Figure 4 shows the typical waveforms of both $\mathrm{AE}$ accumulated count and $\mathrm{AE}$ count rate for $\mathrm{C}-$ and $\mathrm{NH}$-laminae in the threshold of $20 \mathrm{mV}$ during bending tests. Both AE signals in NH-laminae were measured at the early stage of the bending test as compared with C-laminae. As clarified by these previous researches (Yano et al., 2007), this suggested that the gaps and the destruction of based part caused by the starved jointed in the finger-joint were $\mathrm{AE}$ source.

\section{AE generation load}

The load when $\mathrm{AE}$ generation started was assumed as the AE generation load. Figure 5 shows the relationships between $\mathrm{AE}$ generation load and threshold in $\mathrm{C}-$ 


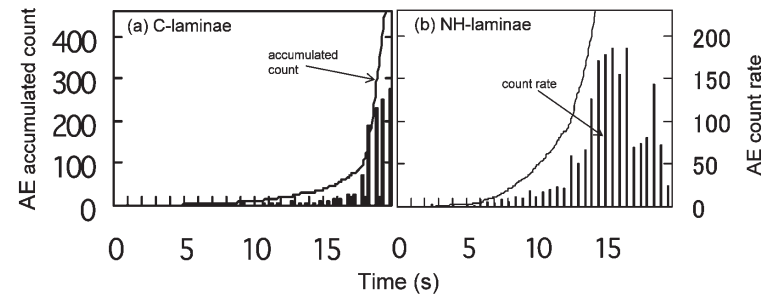

Fig. 4. Typical waveforms of both $\mathrm{AE}$ accumulated count and $\mathrm{AE}$ count rate.

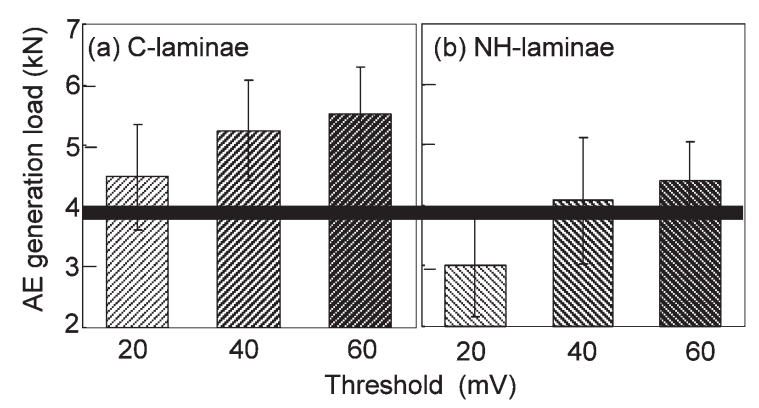

Fig. 5. Relationships between $\mathrm{AE}$ generation load and threshold.

and NH-laminae. In each threshold, the $\mathrm{AE}$ generation load of NH-laminae showed a small value as compared with that of C-laminae, and the $\mathrm{AE}$ generation load showed a small value with decreasing threshold. In these thresholds of the test, the $\mathrm{AE}$ generation load showed the smallest value in $20 \mathrm{mV}$. Therefore, it became clear that the difference between $\mathrm{C}-$ and $\mathrm{NH}$-laminae at the early stage during bending test will be able to detect in the setting of the threshold to $20 \mathrm{mV}$.

\section{Bending strength properties}

Figure 6 shows the relationship between MOR and MOE for each C- and NH-laminae. Both MOR and MOE of NH-laminae showed small values than that of C-laminae. Thus, it was clear that the starved joints without hardener greatly influence the decrease of bending strength properties of finger-jointed laminae. In addition, this tendency corresponds to that of AE generation load (Fig. 5). Therefore, these results suggested that $\mathrm{AE}$ technique was promising for detection of the decrease of strength properties of laminae.
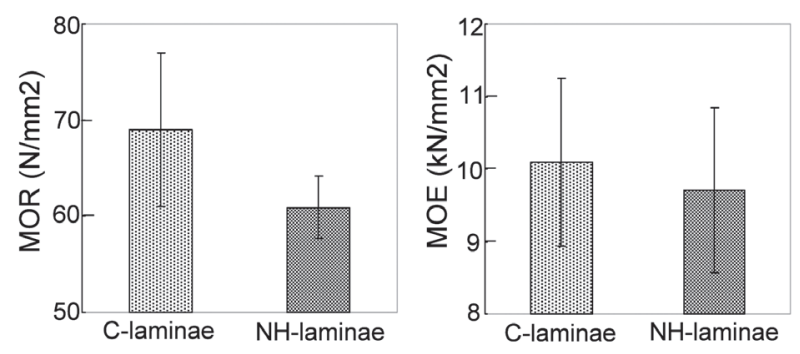

Fig. 6. MOR and MOE for each $\mathrm{C}-$ and $\mathrm{NH}-$ laminae.

\section{Verification test}

From the result of the AE generation load as shown in Fig. 5, the bending load needed to detect $\mathrm{NH}$-laminae under the $20 \mathrm{mV}$ in threshold was set to $4 \mathrm{kN}$ (detection load), and the verification test was conducted under the detection load. $\mathrm{C}-$ and $\mathrm{NH}-$ laminae were prepared ten specimens, respectively. In the verification test, the process was performed in three stages as follows; first, the detection load was given to each laminae under the same condition of the previous bending test. Secondly, the detection load was unloaded, and the usual bending test for confirming the bending strength properties was conducted again. Finally, the relation between the AE generation load and the bending strength properties was examined.

The obtained results are shown in Table. 1. This table shows the AE generation load when the detection load was given to NH-laminae. From this result, the AE generation was admitted under the detection load of $4 \mathrm{kN}$ in seven in ten NH-laminae. In this condition, it became clear that NH-laminae can be detected at the probability of about $70 \%$. Figure 7 shows MOE and MOR of C-laminae when the beding test was conducted after unloading. For the sake of comparison, the value of C-laminae in the usual bending test is added in Fig. 7. Thus, it became clear that the bending strength properties of laminae was unaffected in the detective load of $4 k N$ because the difference between MOR and MOE by the presence of the detection load was not admitted.

From these results, in the case of loading to the finger-jointed part of laminae in $4 k N$ as the detection load,

Table 1. Result of verification test

\begin{tabular}{cc}
\hline NH-lamine & AE generation load $(\mathrm{kN})$ \\
\hline 1 & 2.9 \\
2 & - \\
3 & 2.2 \\
4 & - \\
5 & 2.5 \\
6 & - \\
7 & 3.1 \\
8 & 3.6 \\
9 & 2.3 \\
10 & 3.6 \\
\hline
\end{tabular}
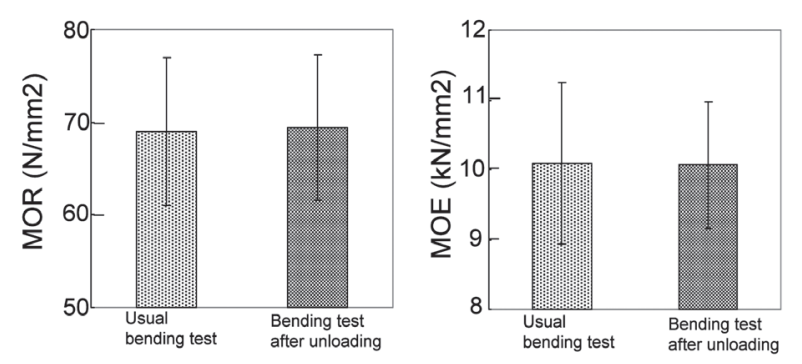

Fig. 7. MOR and MOE for C-laminae after unloading. 
the possibility of the detection of the starved joints by $\mathrm{AE}$ with the jig as a non-destructive method was suggested without influencing to the bending strength properties of the laminae.

\section{CONCLUSIONS}

In this study, hinoki finger-jointed laminae with starved joints were prepared, and the evaluation of finger-joint properties was conducted with a special attachment (jig) for installing the $\mathrm{AE}$ monitoring method into the production line of laminae. That is, bending tests for these laminae with the jig were performed, and AE generated during the bending test was measured along with the load. Then, AE characteristics and bending strength properties of these laminae were examined. In addition, the verification test with the jig under the bending load for detecting the laminae with starved joints was performed. The main results are summarized as follows:

1) $\mathrm{AE}$ signals of laminae with starved joints in the threshold of $20 \mathrm{mV}$ were measured at the early stage of the bending test as compared with laminae without starved joints.

2) The $\mathrm{AE}$ generation load of the laminae with starved joints showed a small value and showed the smallest value in $20 \mathrm{mV}$. Therefore, it became clear that $\mathrm{AE}$ technique in the setting of the threshold to $20 \mathrm{mV}$ will be promising for the detection of the difference between the laminae with starved joints and without starved joints at the early stage during bending test
3) MOR and MOE of the laminae with starved joints showed small values than that of without starved joints. Thus, it was clear that the starved joints without hardener greatly influences the decrease of bending strength properties of finger-joint laminae.

4) From the result of the verification test with the jig under the detection load $(4 \mathrm{kN})$ and the threshold $(20 \mathrm{mV}$ ) for the detecting the laminae with starved joints, it became clear that the laminae with starved joints could be detected at the probability of about $70 \%$ under these conditions. The bending strength properties of laminae were unaffected in $4 \mathrm{kN}$ as the detection load.

From the above results, in the case of loading to the finger-jointed part of laminae in $4 k N$ as the detective load with the jig, the possibility of the detection of the starved joints by $\mathrm{AE}$ as a non-destructive method was suggested.

\section{REFERENCES}

Ohuchi T, Ando M, Fujimoto Y, Morita, Fujimoto N, Murase Y 2004 Non-destructive evaluation of strength properties of sugi finger-jointed laminae (in Japanese). The summary of the 22nd Wood Technological Association of Japan (Osaka): 85-86

Yano K, Ohuchi T, Murase Y, Fujimoto Y, Morita H 2007 Evaluation of sugi finger-jointed laminae with a knot and starved joints by acoustic emission. Journal of the Faculty of Agriculture Kyushu University, 52(1): 111-116 